University of San Diego

Digital USD

Undergraduate Honors Theses

Theses and Dissertations

Spring 5-22-2017

\title{
Analyzing the Social Change Model In the Context of Women's Rights to Education
}

Abigail R. Solnet

University of San Diego

Follow this and additional works at: https://digital.sandiego.edu/honors_theses

\section{Digital USD Citation}

Solnet, Abigail R., "Analyzing the Social Change Model In the Context of Women's Rights to Education" (2017). Undergraduate Honors Theses. 43.

https://digital.sandiego.edu/honors_theses/43

This Undergraduate Honors Thesis is brought to you for free and open access by the Theses and Dissertations at Digital USD. It has been accepted for inclusion in Undergraduate Honors Theses by an authorized administrator of Digital USD. For more information, please contact digital@sandiego.edu. 
Running Head: The Social Change Model

Analyzing the Social Change Model

In the Context of Women's Rights to Education

\author{
A Thesis \\ Presented to \\ The Faculty and the Honors Program \\ Of the University of San Diego
}

By

Abigail Ruth Solnet

Leadership Studies

2017 


\section{Table of Contents}

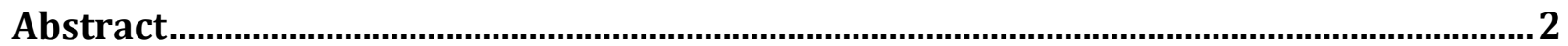

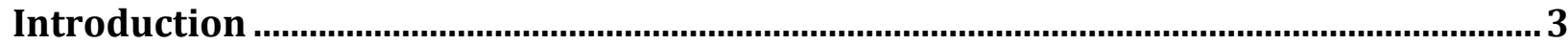

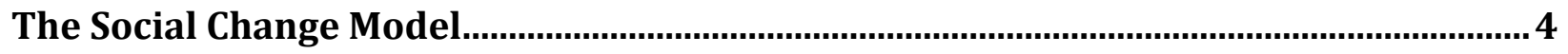

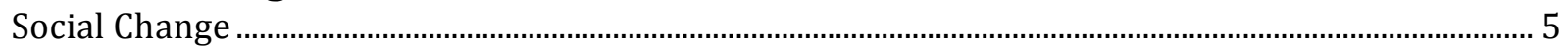

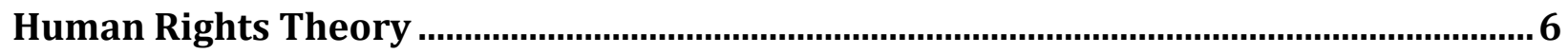

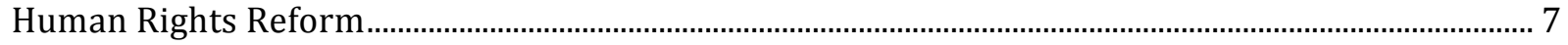

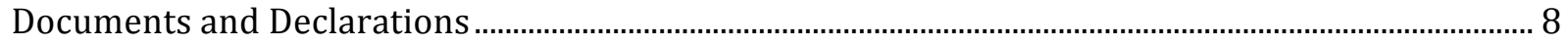

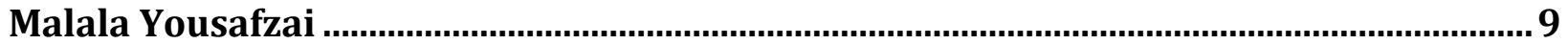

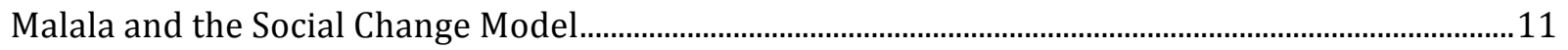

Emma Watson .................................................................................................................................... 15

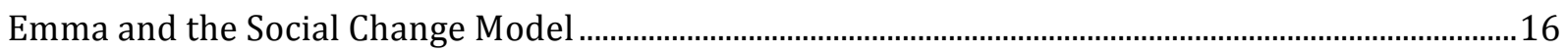

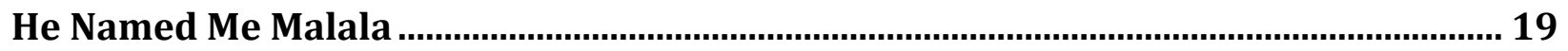

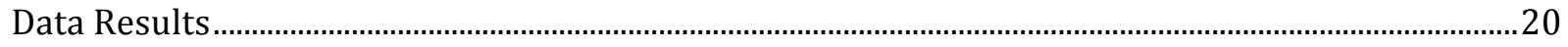

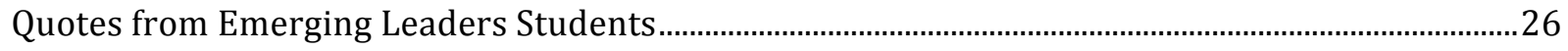

Critique of the Social Change Model.............................................................................. 26

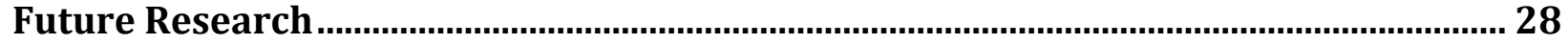

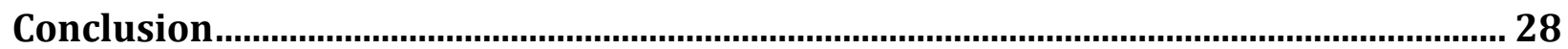

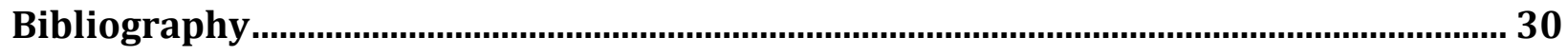

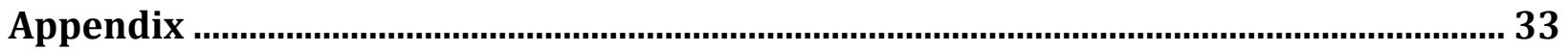

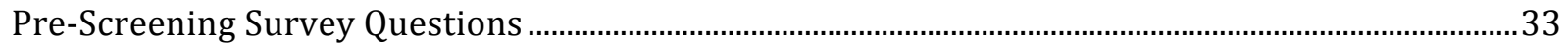

Post-Screening Survey Questions …………………..................................................................................... 35 


\section{Abstract}

For my Honors Senior Thesis, I analyzed a leadership theory called the Social Change Model. This model was created by Susan Komives, and consists of the "7 Cs" of leadership. These Cs are divided into individual (consciousness of self, congruence, commitment), group (collaboration, common purpose, controversy with civility), and societal/community (citizenship) values. These values are important in creating positive social change.

I applied the Social Change Model to the context of the human right to education. This human right is currently being violated in various areas around the world. Since human rights are intersectional, it is important to look at populations who are marginalized, specifically women. I did a case study to see how the Social Change Model applies to Malala Yousafzai and Emma Watson and their work to advocate for women's rights to education. I offered insights into how they utilize the values of the Social Change Model, as well as critiques on the limitations of the Social Change Model.

I conducted primary research within the University of San Diego community by hosting a screening of the film "He Named Me Malala" and did surveys to see if people can understand the Social Change Model in the context of this film. Additionally, Emerging Leaders students had the opportunity to write reflection papers about the film, and I used quotes from these papers to demonstrate how students can better understand the Social Change Model through real-life examples. Overall the goal of the research was to better understand the Social Change Model and how it can be applied to the context of women's rights to education. 


\section{Introduction}

When conducting research for this thesis, I can across a quote from the book and film Half the Sky by Nicholas Kristof. He said, "One of the great failings of the American education system, in our view, is that young people can graduate from university without any understanding of poverty at home or abroad" (Kristof 2012). As I complete my undergraduate degree at the University of San Diego, I reflect on my own college experiences. I am fortunate to be at a Changemaker university that challenges everyone to make a positive impact in the local and global community. I have taken classes that talk about inequality, social justice, poverty, and human rights. I am in the $7 \%$ of the world population that will have a college degree (Reilich 2016), and I have studied abroad and seen the impacts of poverty and lack of education firsthand. I am extremely grateful for my education, however many college students do not learn about inequality, and do not realize how fortunate they are to be receiving an education.

I believe education is important, because when I look out into the world, there are countless examples of problems caused by inequality. What I've realized is that I cannot solve all of these problems myself. However, through educating people, we can collectively solve these problems. If there are people who are experiencing violations of human rights, such as a lack of food, water, shelter, or are experiencing violence, sexual trafficking and abuse, these violations can be stopped through education. People can tackle issues in their own communities and create sustainable solutions if they receive their basic right to education.

Through research, I've learned about the impacts of inequality and lack of education for women. Many women around the world do not receive an education. Being an educated woman 
myself, this resonates with me, and encourages me to focus my work on the inequalities that women face, and how to address them.

When thinking of ways to address inequalities, it is important to understand leadership and the process of creating change. These problems cannot be addressed immediately or by one person alone. One must remember that leadership is a process, and not a formal position. Anyone can, and everyone should, partake in the leadership process. Through understanding leadership models and theories, as is the aim of this research, we can all do our part to value education, understand equality, and create positive change in the world.

\section{The Social Change Model}

This thesis focuses on the Social Change Model, which is a leadership theory developed by Susan Komives in the textbook Leadership for a Better World. This leadership model was created for college students "who want to learn to work effectively with others to create social change over their lifetimes" (Komives 2009). The model (as shown below) consists of the seven Cs of leadership divided into three types of values. First there is the societal value of citizenship. Next are the group values of collaboration, common purpose and controversy with civility. Finally there are individual values of consciousness of self, congruence and commitment.

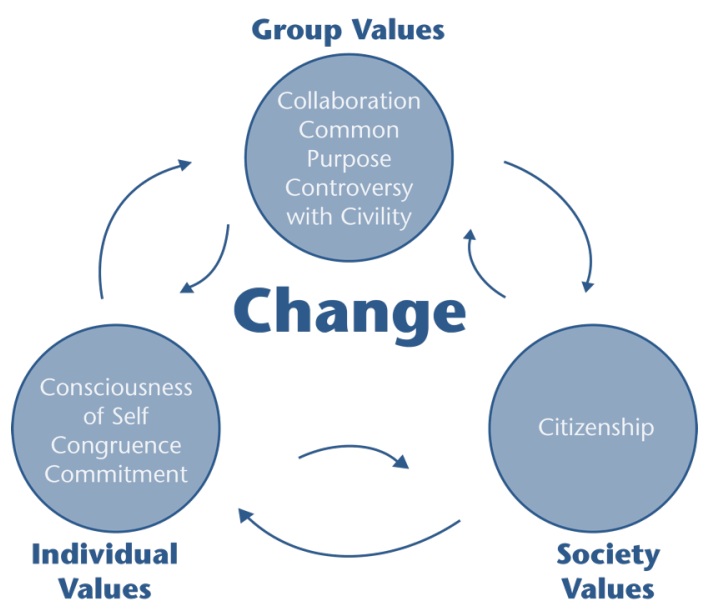




\section{Social Change}

Each of the $7 \mathrm{Cs}$ will be defined in later sections of the paper, but it is important to begin with a definition of change. In order to understand social change, one can "contrast it with charity and sporadic volunteerism" (Komives 2009). What makes social change different is the focus on the root causes of problems, rather than the surface level iterations. These root causes are complex, and addressing them requires "multiple solutions, not just one quick fix" (Komives 2009). Another dimension of social change is the emphasis on collaboration. Rather than being a dichotomy, there is a unique relationship where the "individual and the community reinforce each other" (Komives 2009). Overall change is defined by Komives as "improving the status quo, creating a better world, and demonstrating a comfort with transition and ambiguity in the process of change."

Just as it is important to recognize that change is a process, one must understand that leadership is also a process. Typically leadership is associated with a formal position or title that gives a person authority, but the new leadership literature suggests that leadership is a process that anyone can take up. It is not simply one person acting as a leader, but "involves collaborative relationships that lead to collective action, grounded in the shared values of people who work together to effect positive change" (Komives 2009). This new way of understanding leadership brings to light how leadership is "multidirectional, collaborative, networked, and process oriented" (Komives 2009). Practicing leadership is a values-based process, and the important of values is demonstrated throughout the Social Change Model.

One thing to note is that leadership theory can often be abstract. One can probably acknowledge that a value such as "collaboration" is important for leadership, but the actual definition and application can be hard to understand. This is the premise for which this thesis is 
based on. In later sections, each of the $7 \mathrm{Cs}$ will be defined with examples from the context of Malala Yousafzai and Emma Watson's advocacy work for the human right for education. However before jumping into this analysis, it is important to have an understanding of human rights theory.

\section{Human Rights Theory}

The human rights theory used in this thesis derives from the Goodhart textbook, Human Rights: Politics and Practice (2012). At their core, human rights are socially constructed. There is debate whether or not they are universal or historically and culturally contingent, but in sum they are constructs created by people in society (Goodhart 2012).

Another central concept in human rights theory is the fact that they are indivisible, interrelated, and intersectional. Human rights are indivisible because no human right is secure unless all rights are secured (Goodhart 2012). This means that all human rights must be protected, and one cannot pick and choose which ones to uphold. Human rights are also interrelated, because the rights of all people are interdependent. Since "no person's rights are secure unless all people's rights are secure," (Goodhart 2012), it is important to protect human rights for everyone, not just specific populations. Finally human rights are intersectional. This component is crucial in this thesis because one needs to "understand how different mechanisms intersect to produce specific forms of oppression" (Goodhart 2012). There are vulnerable populations who experience multiple layers and forms of oppression. One of these populations includes women; so when a woman experiences a violation for her right to education, chances are she might experience a violation of other rights. These could include a violation of a right to food or housing, or she might experience violence, poverty, or sexual trafficking. The 
intersectional, interrelated, and indivisible nature of human rights highlights the importance of focusing this research on women and their right to education, since they are a highly vulnerable population.

\section{Human Rights Reform}

To enhance our understanding of the Social Change Model in the context of human rights, it's important to look at who is doing the work to create change, and how change occurs. Non-Governmental Organizations (NGOs) tend to be the most common group working to promote human rights. They are "legally constituted, private, not-for-profit organizations that... work on advocacy campaigns, develop and set international human rights standards, monitor human rights violations, and provide service delivery" (Goodhart 2012) in order to uphold human rights. NGOs help create change using the Norms Cascade Model of Norm Socialization, and the Spiral Model of Change.

The Norms Cascading Model demonstrates how beliefs about human rights are translated into global norms. As outlined by Goodhart, phase one is when the repression or violation of human rights occurs, and people begin to believe that this violation is wrong. In phase two, advocacy groups scrutinize the activity of governments and corporations that violate basic rights. These governments and business typically refuse to accept or legitimize these claims. In phase three, the advocacy groups mobilize and pressure governments and businesses to change. Governments and businesses might make tactical concessions and hope that the problem goes away, but it's not until phase four where they will make conscious efforts to improve human rights practices and set higher standards. Phase five is the ideal end, where institutions see themselves as guardians of human rights and conforming to the norm of protecting human rights is automatic. 
The Norms Cascading Model is reinforced and happens concurrently with the Spiral Model of Change. The Spiral Model of Change (Goodhart 2012) emphasizes that change occurs in incremental stages, and requires pressure from both the top-down and bottom-up approaches. Both the state and non-state actors that are domestic and international have significant roles in creating this change. The steps of change are similar to the Norms Cascading Model, where in the beginning the state initially denies that any human rights abuses are occurring. They begin to make small concessions, and eventually move to more concrete reforms. The ultimate goal is to alter behavior so it's consistent with the internationally recognized human rights norms.

Both of these theories are important in understanding how social change for human rights occur, because addressing the root causes of problems takes time and effort. Change of norms, beliefs, and behaviors do not occur overnight, and often change in legal policy and action requires pressure from external groups like NGOs. When looking at examples of people and groups who are advocating for the right to education, keep in mind that this reform is slow and requires long-term effort.

\section{Documents and Declarations}

There are several documents and declarations that address the human right to education. Many countries agree upon these documents and declarations, however they are very difficult to uphold and enforce. The first example is the Universal Declaration of Human Rights (UDHR) Article 26, which states, “(1) everyone has the right to education. Education shall be free, at least in the elementary and fundamental stages. Elementary education shall be compulsory." Similar articles are written in the International Covenant on Economic, Social, and Cultural Rights (ICESCR) Article 13, which declares that "education shall be directed to the full development of the human personality and the sense of its dignity, and shall strengthen the respect for human 
rights and fundamental freedoms." Additionally the United Nations (UN) Convention on the Rights of the Child (CRC) Articles 28 and 29 include components highlighting that states should cooperate in the "elimination of ignorance and illiteracy throughout the world" and the preparation of children for life in free society, with the "spirit of understanding, peace, tolerance, equality of sexes, and friendship among all peoples."

While these documents and declarations represent the high ideals of universal human rights for all, there are still "nearly 58 million primary school-age children [who] are not in school. More than half of these children are girls, and 75\% of them live in sub-Saharan Africa or South Asia" (Kristof 2012). There is clearly an ongoing violation of the right to education (particularly for women) today. These documents and legislation outline the right to education, but lack mechanisms to monitor and enforce compliance. So what does one do when these human rights violations persist? Non-Governmental Organizations (NGOs) and everyday people step up to the plate to create positive change. The next portion will look at how the Social Change Model connects to the advocacy work of Malala Yousafzai.

\section{Malala Yousafzai}

Malala Yousafzai is the first example for the case study analysis of the Social Change Model. She was selected as an example because of her work and global presence in advocating for the human right to education. Malala Yousafzai from Pakistan and became known around the world as the girl who was shot by the Taliban because she was outspoken about her right to education. Now she "advocates at local, national, and international levels, for resources and policy changes needed to ensure all girls complete 12 years of school" (Malala Fund). Her current goals are inspired by her life journey. 
Malala was born on July $12^{\text {th }}, 1997$ in the Swat Valley in Pakistan. She grew up in a land where "rifles are fired in celebration of a son, while daughters are hidden away behind a curtain" (Yousafzai 2013). She was named after Malalai of Maiwand, a heroine who "inspired the Afghan army to defeat the British in 1880" (Yousafzai 2013). Her father ran a school, and she grew up attending and excelling in school. When she was 11, she began writing about her experiences living under the Taliban, and speaking out against their oppressive rules. There were periods of her life where girls were banned from attending school, and she commented that "the Taliban could take away our pens and books, but they couldn't stop our minds from thinking... when someone takes way your pens you realize quite how important education is" (Yousafzai 2013). Malala even had to leave her home "as terrorism and extremism raged in my city" (Yousafzai 2014). Throughout these hardships, Malala continued to fight for her education and speak out against the Taliban rule.

In 2011 she received Pakistan's First National Youth Peace Prize for her work in her local community and country for education. Her father was also very vocal about the right to education, and they both became targets of the Taliban. In 2012 at the age of 15, Malala was shot in the head while riding the bus to school. She was hospitalized and transported to England for treatment. She survived the shooting and in 2013 she established The Malala Fund and published her book I Am Malala. The Malala Fund works to amplify the voices of girls and "be a champion for girls' education” (Malala Fund). In 2014 at the age of 17, Malala became the youngest recipient of the Nobel Peace Prize, and in 2015 the film He Named Me Malala was released. At such a young age, Malala has accomplished so much, but continues to strive towards her ultimate goal of equality and education. Malala is an example of someone who is creating social change and is implementing several of the values of the Social Change Model. 


\section{Malala and the Social Change Model}

This next section will define different components of the Social Change Model and provide examples of how Malala implements them. Providing examples of what each of the $7 \mathrm{Cs}$ looks like in action will ultimately create a deeper understanding of the values and how they can be implemented in any social change work.

Citizenship, the societal value, is the first of the 7 Cs that will be analyzed. Citizenship "centers on active community participation as a result of a sense of responsibility to the communities in which people live (Komives 2009). When individuals can see themselves as a part of the larger whole, they are more willing to engage in their community or society. Citizenship requires that people work with others, which "is what links citizenship and leadership so closely" (Komives 2009).

There are several forms of individual civic engagement, but two that Malala practice include advocacy and education. Advocacy focuses on using forms of persuasion "to convince government or corporate decision makers to make choices that will benefit the community" (Komives 2009). While advocacy focuses on influencing governments and businesses, it pairs nicely with education since education focuses on influencing and increasing public awareness of social issues (Komives 2009). Malala meets with global political leaders to drive policy and fiscal change that prioritizes education. She also increases public awareness for the right to education through her film He Named Me Malala, as well as through sharing the stories of girls around the world who have had their right to education violated. She shares these stories online on blog.malala.org and on social media.

It's important to recognize that Malala started her journey in her own community and Pakistani society. She felt a responsibility to serve her community, and that responsibility grew 
to include her global brothers and sisters. On her most recent visit with the Canadian Parliament, she became "the sixth person, and the youngest, to receive honorary Canadian citizenship" (Kestler-D'Amours 2017). Although this citizenship is entirely symbolic, it represents Malala's sense of global citizenship, and how girls from around the world deserve their right to education. Citizenship is the only societal value, but is integral in understanding the Social Change Model. The next value is common purpose, which is one of the three group values.

Common purpose is a group's collective vision, aims, and values. A vision answers the question: "what is the ideal future for this organization?" and it "clarifies the direction" the group needs to move towards (Komives 2009). The aims focus on "why the organization exists," and provides "confidence, clarity and trust" (Komives 2009) for the group. Finally the values address how group "members treat each other" (Komives 2009) and how the group aims and vision will be pursued. It's important that the group's common purpose is created by the group and is supported by individual members. It can be hard to articulate a common purpose, but it is an essential component for leadership and creating change.

Malala has crafted a vision statement that encompasses her long term goal: "To see a world where every girl can complete 12 years of safe, quality education" (Malala Fund). This common purpose is an example of a clear and cohesive goal that unites her supporters. It is also aspirational yet attainable in the long term. This goal drives Malala's decisions and actions, and is present in everything she does. This vision statement is also a bit broad- which can be good as it is all encompassing, but it also doesn't define what safe and quality education actually looks like. The aims in which Malala strives to achieve this goal are described on The Malala Fund website, which says, "We advocate, we invest, and we amplify." This includes doing advocacy work at all levels, and investing in programs and leaders who support girls, and raising public 
awareness by letting girls share their own stories. All of these aims are done in alliance with Malala's values, which will be examined as we talk about congruence.

A person acts congruently when "their inner world of values, principles, and priorities matches their outer world through their decisions and actions, including the way they treat others (Komives 2009). Congruency is an individual value that is about acting consistently with one's values and beliefs. In relation to common purpose, it is important that the vision and aims are congruent and align with values. Congruency can be challenging, and when people "challenge themselves to do the right thing even when it is not convenient" (Komives 2009), it demonstrates their courage and character. It can be hard to stick to one's values, but Malala demonstrates the importance of understanding, acting with, and even defending her values.

Two values that are essential to Malala and her family are the values of education and those taught in her religion of Islam. Malala's grandfather gave her father "a deep love of learning and knowledge as well as a keen awareness of people's rights, which my father has passed on to me" (Yousafzai 2013). Her mother did not go to school, since in her village it seemed pointless when girls "just end up cooking, cleaning, and bringing up children" (Yousafzai 2013). Although her mother never went to school, her father was determined to have their children go to school. He opened and ran his own school, and Malala was always top of her class. This value of education is ingrained in her family, so when it was threatened, her father said, "you can stay there accepting everything from the Taliban or you can make a stand against them" (Yousafzai 2013). Malala's family upheld their value of education, even while being threatened by the Taliban. Their value of education is also rooted in their value of religion.

Many Taliban leaders claimed that Islam teaches women to stay home and take care of children, but Malala said, "Education is our right... just as it is our right to sing. Islam has given 
us this right and says that every girl and boy should go to school. The Quran says we should seek knowledge, study hard, and learn the mysteries of our world" (Yousafzai 2013). Malala is very proud of her faith, and her family holds true to these values. Malala commented on her values in an interview with Emma Watson at the Into Film Festival, where He Named Me Malala was shown. Malala said that people are misinterpreting Islam. She said that the word Islam means "peace" and the first word of the Quran means "read" (Emma Watson interviews 2015). Again Malala talks about how her religion encourages everyone to read, learn, and to gain knowledge. When Malala and her family make decisions, they are rooted in these values of education and the teachings of Islam. However those like the Taliban disagreed, and this brings to light the question- what happens with individual values don't align with the group, community, or societal values? This challenge can be approached through the group value of controversy with civility.

The aim of controversy with civility is to "create a culture in the group that welcomes controversy" (Komives 2009). Controversy arises when people "hold contrasting perspectives and opinions [and] are encouraged to share their views" (Komives 2009). It's important to understand that controversy is different than conflict. In situations with conflict, people are divided on either side of a topic and argue to try to persuade other people. Controversy with civility encourages groups to meet in a circle and share their various opinions in a respectful way. Groups who value collaboration understand the need for diverse perspectives and opinions in order to make the best possible decisions. So again this relates to the question posed about what happens when individual values or beliefs differ from the group values? In the case of Malala, she protests and stands up against the Taliban and their beliefs.

If one looks at the approaches to disagreement that Malala takes, one will see that she responds with openness, respect, and empathy. In the film He Named Me Malala, the interviewer 
asked Malala how she feels towards the men who shot her. She responded by saying she wishes she could have a conversation with him where they share their opinions and beliefs, listen to each other, and learn from each other (Guggenheim 2016). She does not hate the people who hurt her, but rather wishes she could help educate them. Malala handles the difference of opinion with civility and respect, whereas the Taliban resorts to conflict and violence. Malala sets an example of how controversy with civility can be done on a large scale, and her example can be translated into other group settings as well. It's also amazing that this controversy has elevated Malala's voice and her cause. Malala commented, "They thought that the bullets would silence us, but they failed. And out of that silence came thousands of voices" (Anderson 2013).

Malala has become a global leader in creating change. Although social change has already been defined, this section will be concluded with a famous quote that encompasses Malala's work for the human right to education. In her speech to the United Nations in 2013, she said, "Let us pick up our books and our pens, they are our most powerful weapons. One child, one teacher, one book, and one pen can change the world. Education is the only solution. Education first" (ABC News 2013).

\section{Emma Watson}

The next case study looks at how the Social Change Model relates to the work of Emma Watson. Emma is not only a renowned actress, but has become an advocate for gender equality and education. She has collaborated with Camfed, the Campaign for Female Education, which "tackles poverty and inequality by supporting marginalized girls to go to school and succeed, and empowering young women to step up as leaders of change" (Camfed). Through her work with Camfed, she traveled to Zambia and "saw first hand how child marriage crushes the prospects of 
individual girls ... [since] the longer a girl stays in school... the less likely she is to get married and become pregnant during her teenage years" (Gloria Steinem and Emma Watson 2016). Emma Watson has pledged to support Camfed to help remove barriers so that these girls in Zambia can attend school as an alternative to early marriage.

Emma was also selected to be a United Nations Goodwill Ambassador for Women, and the spokesperson for the He for She campaign to end gender inequality. The He for She campaign invites men into the conversation of gender equality, so that everyone can work together to achieve equality. She addressed the United Nations and spoke about how if we do nothing, "it will take 75 years before women can expect to be paid the same as men for work... [And] not until 2086 will all rural African girls have secondary education" (Emma Watson UN Speech 2014). Overall Emma Watson is another example of how to create social change for the right to education.

\section{Emma and the Social Change Model}

Like before, this section will define the remaining values of the Social Change Model and provide examples of how Emma implements them.

Collaboration is the first value being implemented by Emma Watson. Collaboration is one of the group values, and involves "how people relate to each other" and the process of “developing common visions, goals, and purpose" (Komives 2009). Collaboration is inclusive, based on relationships within groups, and require an understanding of identities and diversity. As described by the intersectional nature of human rights, individuals have "multiple dimensions of identity... that intersect with one another" (Komives 2009). Having group members with various identities and diverse backgrounds is "both the strength and the challenge of collaboration" (Komives 2009). Diversity is at the core of both collaboration and controversy with civility, and 
it's important that group members build trust and are respectful when sharing various perspectives. Some of the dimensions of identity include race, ethnicity, national origin, sexual orientation, class, age, ability, religion, and gender. Gender identity is at the core of the right to education and the work Emma Watson is doing with the He for She campaign.

The He for She movement invites men to the conversation of gender equality. Those who advocate for equal rights for everyone, regardless of gender, realized that the conversation has been mainly focused on and coming from women. However in order to make progress, both men and women need to collaborate and work together. In her address to the United Nations, Emma invites men to the conversation, and shares how gender equality is their issue too. If men are free from the gender stereotypes and the harm that comes from hyper-masculinity, then everyone will benefit. The collaborative nature of the He for She movement encourages diversity of identities, and yet unites all people towards a common purpose. The response that the campaign has received was immense, and thousands of men are signing up to support and fight for gender equality. Gender equality is a topic at the center of the right to education, because both men and women need to be educated, and support the education of others. One aspect of education that everyone should undertake is becoming more self-aware, which is described in the next value, consciousness of self.

The individual value of consciousness of self refers to "people's awareness of their own personality traits, values, and strengths, as well as their ability to be self-observers who are mindful of their actions, feelings, and beliefs" (Komives 2009). This self-awareness comes from personal introspection, reflection, and mindfulness. Having a deeper understanding of oneself is related to the importance of identities in collaboration. One should understand their own identities and how it influences their leadership practices. 
If a person understands how their gender identity impacts their leadership, they can better understand how to create social change. There are leadership traits and qualities that are traditionally associated with a specific gender, but the He for She campaign rethinks how we approach gender. Emma says that men and women "can be both sensitive and strong" (Emma Watson UN Speech 2014). Gender should not be understood in a traditional binary way, but rather as a spectrum. If people want to create social change, they can, and must practice leadership that is decisive and powerful, as well as empathic and understanding. These qualities do not belong to a single gender, but can be practiced by everyone. Through self-awareness and reflection, individuals can see how gender impacts their leadership style, and create change in their own lives. Once an individual understand himself or herself, they can understand others, and collaborate to create social change. Gender equality and the right to education can only be changed if individuals understand themselves and live congruently with those values. Congruence is the value that connects Consciousness of Self with the final individual value, Commitment.

Being committed to something "implies intensity and duration" (Komives 2009), which creates the energy that drives social change. Being truly committed "comes from within... [And] is compelled by intrinsic motivation" (Komives 2009). Once someone is aware of their personal values and beliefs, they should act congruently with those values and use them to focus on their own passions. Often a person's "passion and commitment is developed from personal experience" (Komives 2009). This is the case for Emma, who is committed to He for She because of her own personal experiences.

In her address to the United Nations, Emma Watson shares how she was called bossy, sexualized by the media, dropped out of sports she loved, and observed that her male friends 
were unable to express their feelings. These personal experiences have shaped her values and beliefs, and make her committed to the cause of gender equality and the right to education. This sense of commitment extends to her work with Camfed, and even into her acting career. At the MTV Movie Awards in May 2017, Emma “made a potent call for breaking down gender categories as she scooped up the gender-neutral film acting prize at the MTV Movie and TV Awards" (Shea 2017). Emma Watson exemplifies the importance of being committed to your values in every aspect of your life as a way to create social change.

Just as the section about Malala Yousafzai concluded with a quote about change, this section about Emma Watson will end with the poignant message from her address to the United Nations. Emma Watson is actively working towards gender equality, especially in the realm of education. In this speech, she sums up the importance of individual commitment in the overall collaborative effort for social change. When she reflects about the work that needs to be done for gender equality, she asks herself, "If not me, then who? If not now, then when" (Emma Watson UN Speech 2014)?

\section{He Named Me Malala}

Through the process of defining and analyzing the values of the Social Change Model, one question that came up is "how can I, as an individual, get involved?" I personally wondered how I could contribute to the work of advocating for women's rights to education. When researching Malala, there was a definitive call to action on how to get involved. The two main ways to contribute were to donate money and watch the film screening of "He Named Me Malala." The next section will dive into research testing to see if film screenings are an effective way to change behavior and intentions at the University of San Diego (USD). 
The research was set up in two parts; the first component involved surveys before and after the film screening. The surveys can be found in the Appendix section. The questions were almost identical before and after as a way to test the impact of film screenings. The pre-screening survey was created on Qualtrics, and was sent out to the general USD community via social media and email. The pre-screening survey had 116 completed responses that were used in analysis. The film was shown on USD's campus on April $4^{\text {th }}, 2017$, and immediately after the screening, those who watched the film were encouraged to fill out the post-screening survey on their mobile devices. The post-screening survey had 30 responses, and came only from those who watched the film. One note about this methodology is that the post-screening survey only tests short-term behavior and intentions, and does not reflect the longer-lasting impacts.

The second aspect of the research involved the opportunity for Emerging Leaders students to attend the film. They had the option to write a 2-3-page reflection paper for extra credit, and gave their permission that quotes from these papers could be used in this research. All quotes will remain anonymous and the option to participate in this research did not impact their grade in the class. There were five students in total who participated in this component of the research. The goal was to see how students were able to connect the film to the Social Change Model, and provide the opportunity for them to share their personal reflections on the film. The next sections share the results from the analysis of the surveys and the quotes used from the Emerging Leaders students.

\section{Data Results}

Since this research is stemmed within the context of the Social Change Model, the first question asked people about their familiarity with the model. At the beginning of the film screening, I presented the Social Change Model, and challenged the audience to reflect on the 
values throughout the film screening. The data results showed that through this integration of the theory and the film screening, people became more familiar with the Social Change Model. The light blue represents the pre-screening survey, while the dark blue represents the post-screening survey. These results suggest that film screenings are not only an effective way to increase awareness, but can also be an educational tool to teach a theory or lesson.

\section{How familiar are you with the Social Change Model}

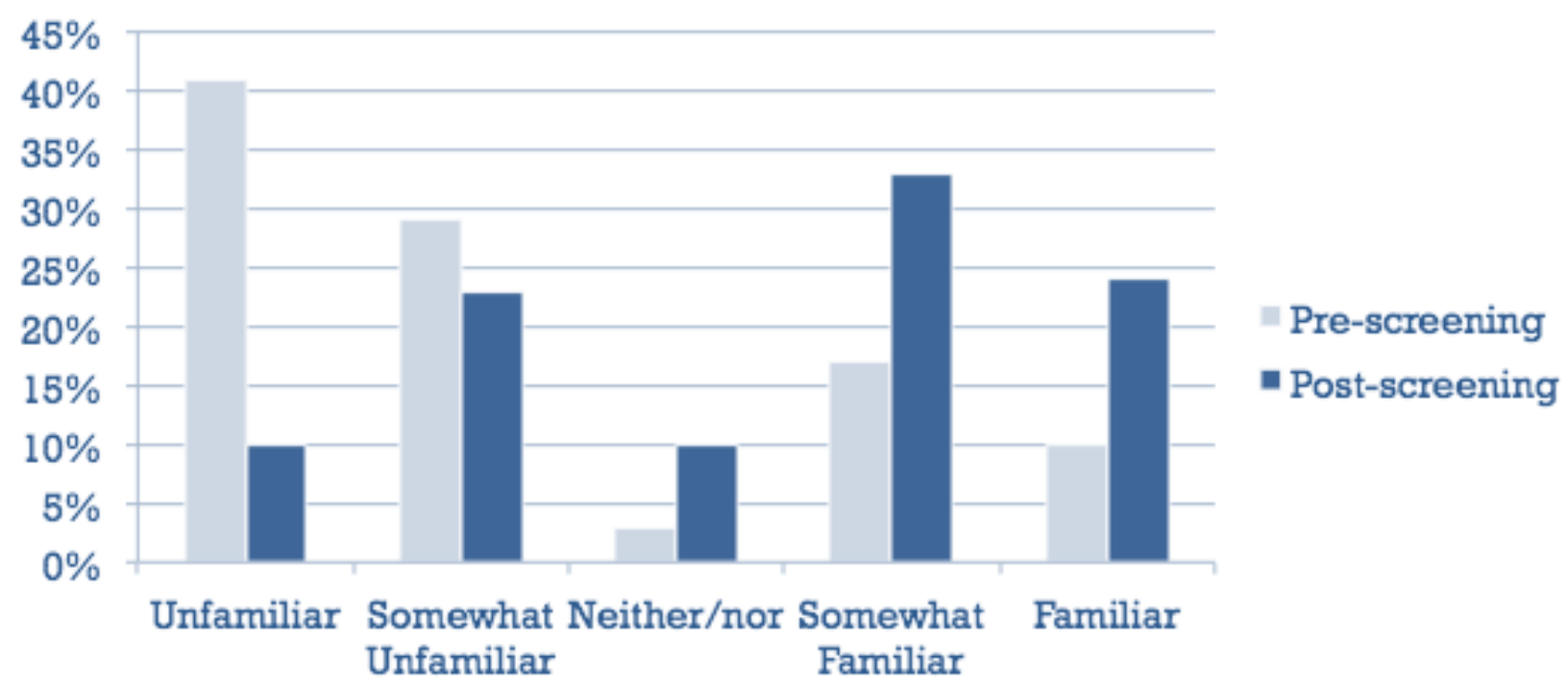

The next area of focus determines whether film screenings impacted people's likelihood to become involved or change behavior. Based on the research, there was an increased likelihood to donate money to the Malala Fund and sign up for emails after watching the film. This is exciting news, since the purpose of this research was to measure the change in behavior that is caused by watching the film. 


\section{Donate money}

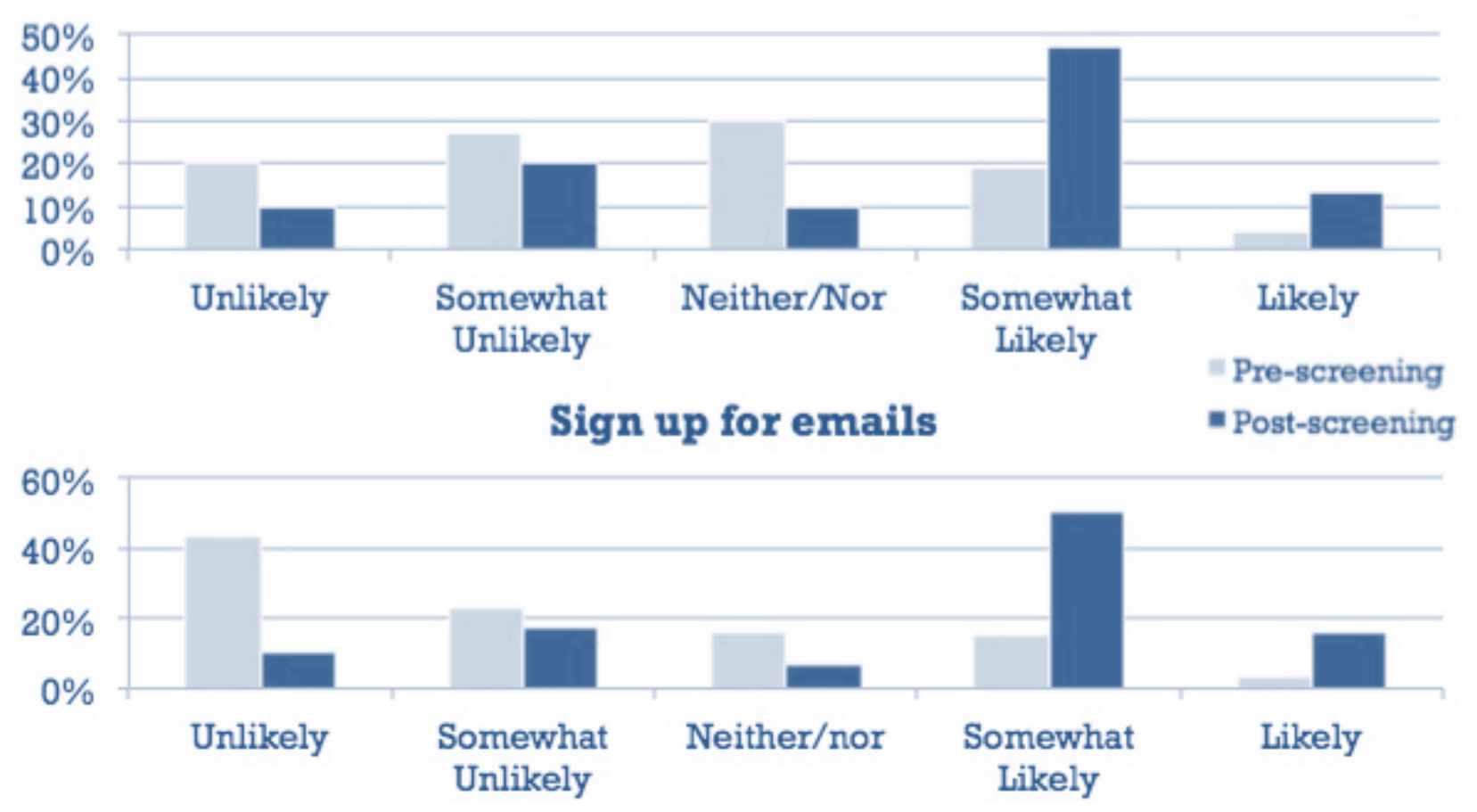

In order to dig deeper, an open-ended question was asked about what would increase one's likelihood to get involved with education advocacy. Some common themes emerged, including having an increase in awareness and information about education. This is important since one purpose of hosting a film screening is to increase awareness. Another theme included having opportunities on campus and in the local community to get involved, beyond just donating money. This reflects the nature of the survey participants- most being millennial college students who don't have spare income to donate, but would rather get involved and see the direct impact they can make. Other factors included having personal experience with the topic, or knowing someone who is personally impacted. Again this can be addressed through film screenings, since the visual nature of the medium allows for story telling and empathy building, as audiences have a way to connect with the people in the movie. Some participants said that a 
film or presentation would increase their likelihood to get involved, and the last component was just having more time and resources in general.

The next aspect looks at only the post-screening survey, and whether people would recommend this film to a friend. This measurement is an important way to measure impact, since word of mouth is a powerful way to spread awareness. Also, people take recommendations seriously, and would only recommend something that reflects their own personal values and beliefs. Overall, $100 \%$ of the participants were likely or somewhat likely to recommend the film to a friend. Again this is exciting and important since word of mouth and recommendations are powerful ways to create change.

\section{Likelihood to recommend film}

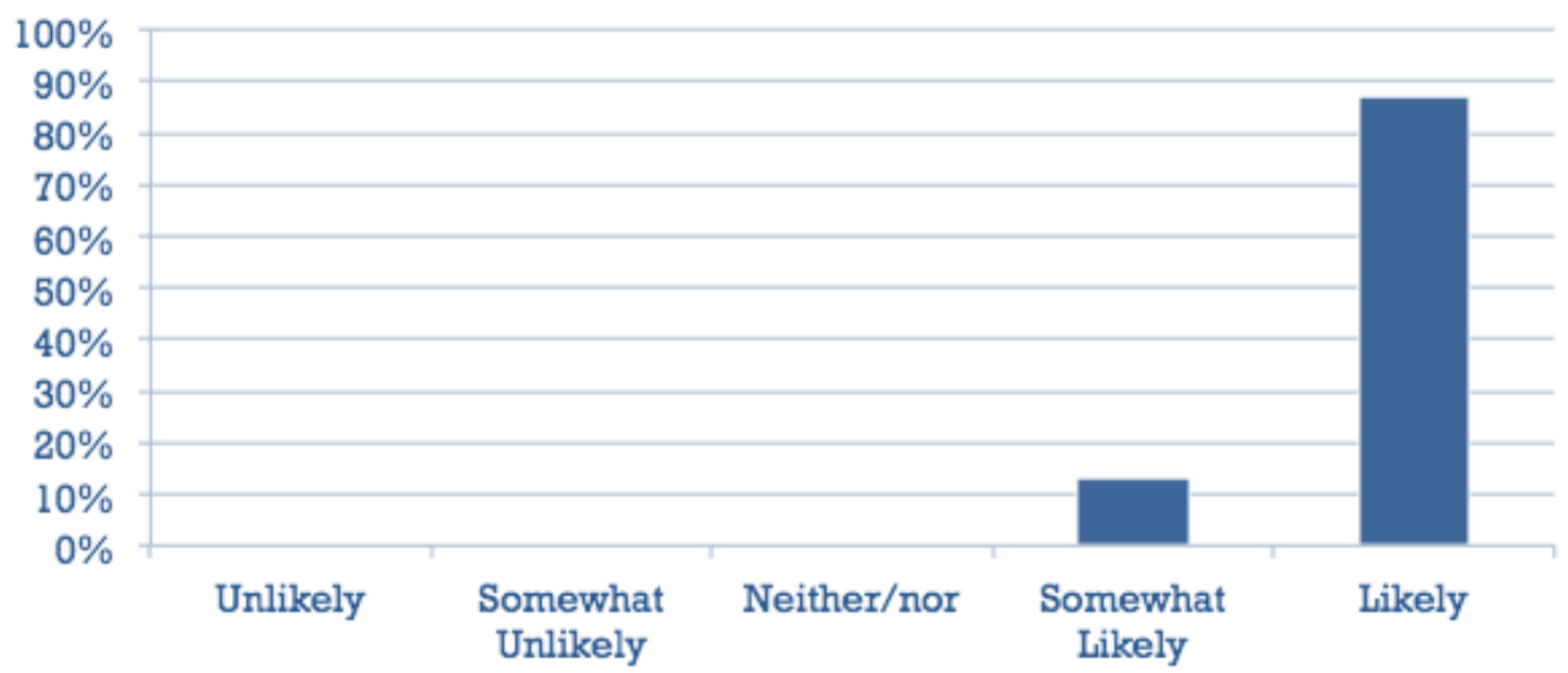

After this initial analysis, I was interested in looking at the impacts of gender on this research. The results were broken down based on the selected gender preference, and it turns out that overall more women than men participated in this research. The lighter blue represents men, and the darker blue represents women. 

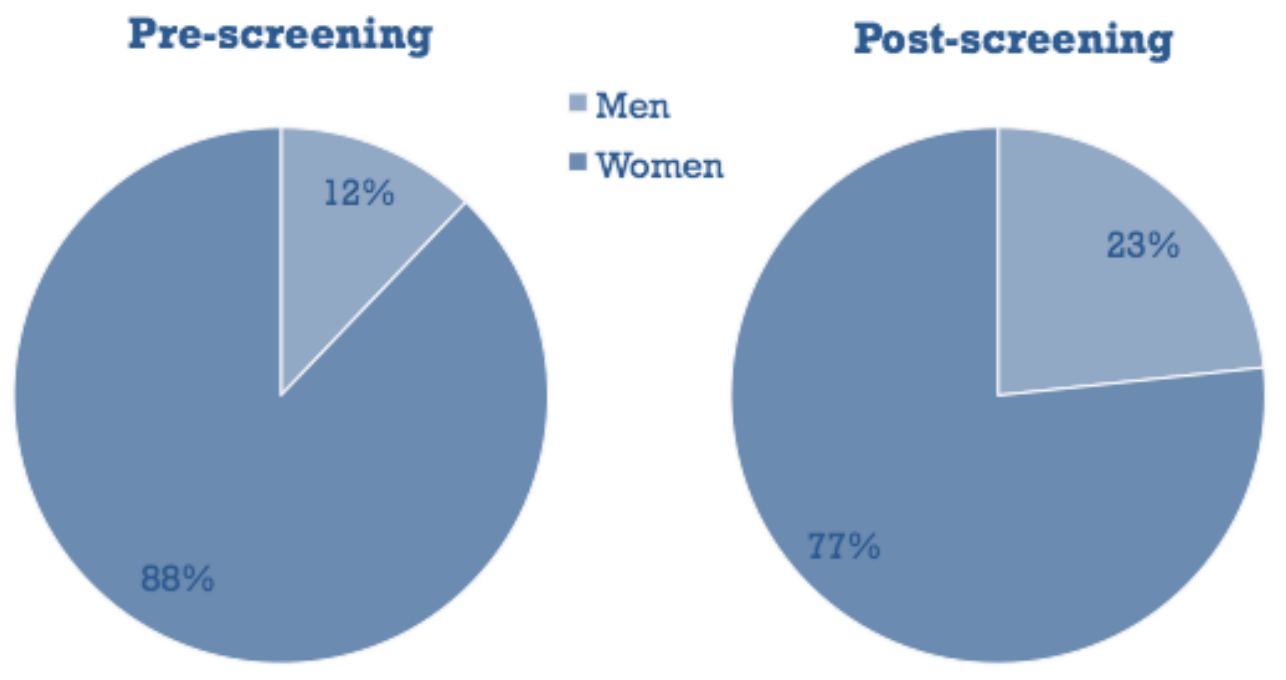

These results raise questions about why there was such a large gender discrepancy.

Perhaps it is reflective of the topic, and that women might be more interested in learning about and discussing women's rights to education? Or perhaps it represents the pool of participants, since USD has more women than men? Further research would be necessary to determine the influencing factors in the gender discrepancy.

Out of the men and women who took the pre-screening survey, more women than men have heard of both Malala Yousafzai and the film.

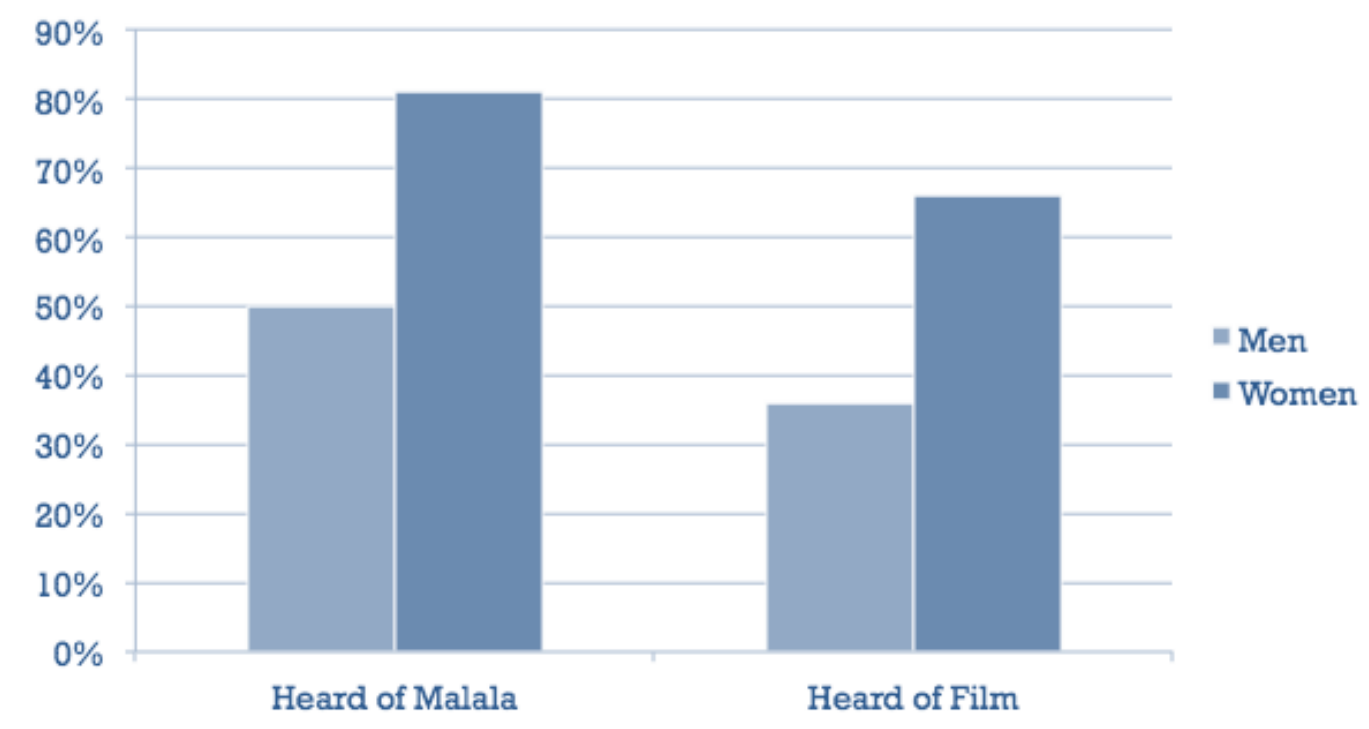


This gender difference is expected based on the previous data analysis, but led to the last question, about whether there were gender differences after watching the film. It turns out that after seeing the film, men and women are equally likely to take action. It's exciting to see the gender discrepancies disappear, and to discover that education via film screenings is just as impactful for both men and women. However one should note that again more women than men attended the film screening in the first place.

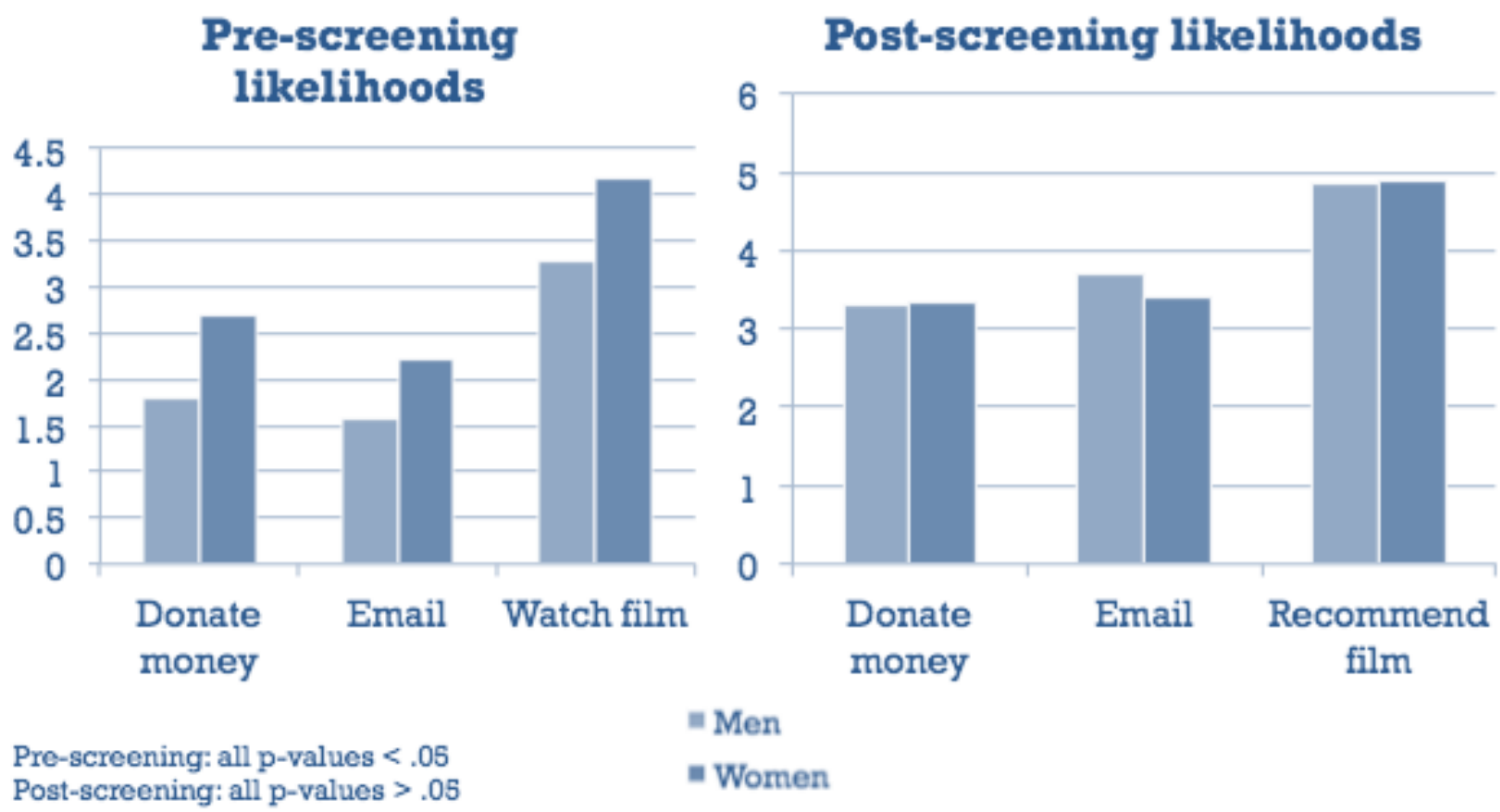

Overall this data analysis delineated that film screenings are an effective way to change behavior and get people to be more aware and involved in the topic of the right to education for women. Although there were differences based on gender, they disappeared after watching the film. The next section looks at the reflection papers written by Emerging Leaders students, and how they were able to connect the film to the Social Change Model. 


\section{Quotes from Emerging Leaders Students}

Some of the students connected the film directly to one of the 7 Cs of the Social Change Model. One student wrote about how Malala "shows commitment to her cause by refusing to stand down or show fear." Another wrote, "This young girl, with great awareness and consciousness of self, shows such immense courage and passion for her purpose." Other students related the film to the overall concept of creating social change. Two students observed the importance of using your voice to create change, which is a key component of Malala's advocacy work. One said, "Malala and her father have the strength and patience to speak out and voice their injustices," while another commented that "she is able to spark movement and change with just the power of her voice." Overall the students found Malala to be an "an incredible role model for what it means to be a leader of positive social justice change."

These students now have a better understanding of the Social Change Model because they can apply it to a real-life scenario. This component of the research supports the first section of analysis that films can be an effective way to educate people and change behavior. However, this research and this leadership theory are not perfect. The next section offers a critique of the Social Change Model.

\section{Critique of the Social Change Model}

The Social Change Model has many positive attributes, however there are some flaws to this theory. It can be a bit formulaic and idealistic. The alliteration can be useful for memorization, but again the values chosen can be abstract and hard to fully understand and apply. In real life scenarios, sometimes people need to prioritize some of the values over others, 
and it can be hard to balance all of the $7 \mathrm{Cs}$. The theory demonstrates the ideal way to create social change, but in real life it can be hard to manage and implement all of the values.

Additionally there is not much focus on the importance of identities (other than being briefly touched on with consciousness of self). Understanding identities is an integral part of practicing leadership, and are at the core of leadership curriculum at USD. The Social Change Model does not offer ways to explore ones own identities; therefore it is necessary to add supplemental resources to incorporate identities into this theory.

In the realm of identities, this research as a whole is limited in the context of gender identities. This research lies within the understanding of gender as a binary, either male or female. It does not go beyond to understand the implications of this theory for other gender identities, including gender queer, non-binary, transgender, or genderless. It also does not focus on these gender identities specifically in the context of human rights, but one can hope that the human right to education is a right to everyone, regardless of ones gender identity.

The final area of critique comes from Komives herself, who said that if she were to add one more $\mathrm{C}$ to the list of values, it would be courage (Komives 2009). Courage can be understood in the context of both Malala Yousafzai and Emma Watson, as they have the courage to raise their voice and create change. Some associate the word courage with bravery. However from the perspective of Brene Brown, who writes and speaks about the power of vulnerability, she shares how courage comes from the Latin word "cour", meaning heart. In her TED talk, she said that courage is "telling the story of who you are with your whole heart" (Brown 2010). This understanding of courage would be a beneficial addition to the Social Change Model, and could lead to new areas of research. 


\section{Future Research}

As mentioned above, extending the Social Change Model to include "courage" could be one area of future research. Other areas of future research could include gaining a deeper understanding of various gender identities and the dynamics associated with their rights to education. It would be valuable to look into other examples of education advocacy, especially at the local level. Malala Yousafzai and Emma Watson are great examples of creating social change globally, but students could still be intimidated and wonder how they can create change in their local community. Additionally it would be interesting to look at other research and responses to the Social Change Model. The final area of future research would be to continue to test the effectiveness of film screenings as a way to change behavior. This research focused mostly on the immediate response of people, so researching the long-term impacts would be a valuable addition. All of these areas for future research would contribute to an overall understanding of the Social Change Model and the human right to education.

\section{Conclusion}

So at the end of the day, why does this research matter? What do I hope you take away from this paper? Ultimately, I hope that you realize that practicing leadership is something we all can, and should do. Just as one practices a sport or an instrument, it takes daily work to create change in the world. Although this research does a case study of two famous and prominent influencers in the world, practicing leadership can be done at any level and done by anyone. I challenge you to reflect on how the values of the Social Change Model play out in your own life. I encourage you to explore what these values mean to you, and how you can use them in your own leadership practice. 
Personally, this research has made me feel grateful for my education. I have attended amazing schools and will be graduating from the University of San Diego with honors, and I hope anyone with an education will feel grateful and appreciative towards their teachers and those who have supported them along the way. I hope those with an education can use this knowledge and privilege to speak out for those who can't. I hope to pay it forward and do my own social change work so that everyone, regardless of gender, can have the opportunity to receive an education.

Equality is an ideal that we must all strive for, because nobody should be oppressed based on their gender, socioeconomic status, or by the color of their skin. No one should be uneducated simply because of circumstances out of their control. I hope that we can one day live in a world where men and women are truly equal.

So why does this matter? I'll just leave you with this, a quote that has inspired my personal journey and exploration of leadership, education, and equality. In the book Sex and World Peace, the author makes this analogy: "The world of humanity is possessed of two wings: the male and the female. So long as these two wings are not equivalent in strength, the bird will not fly. Until womankind reaches the same degree as man, until she enjoys the same arena of activity, extraordinary attainment for humanity will not be realized; humanity cannot wing its way to heights of real attainment. When the two wings... become equivalent in strength, enjoying the same prerogatives, the flight of man will be exceedingly lofty and extraordinary" (Hudson 2012). 


\section{Bibliography}

ABC News. (2013, July 12). Girl Shot in Head by Taliban, Speaks at UN: Malala Yousafzai United Nations Speech 2013. Retrieved May 04, 2017, from https://www.youtube.com/watch?v=QRh_30C816Y

Anderson, B. Standing With Malala's Fund - CNN.com. Retrieved February 20, 2017, from http://www.cnn.com/2013/10/10/world/iyw-malala-fund/index.html

Brown, B. (2010, June). The power of vulnerability. Retrieved May 14, 2017, from https://www.ted.com/talks/brene_brown_on_vulnerability

Camfed. Retrieved May 07, 2017, from https://camfed.org/

Convention on the Rights of the Child. (n.d.). Retrieved February 20, 2017, from http://www.ohchr.org/EN/ProfessionalInterest/Pages/CRC.aspx

Emma Watson interviews Malala Yousafzai Nobel Peace Prize. (2015, November 04). Retrieved May 04, 2017, from https://www.youtube.com/watch?v=NKckKStggSY

Emma Watson UN speech. (2014, September 21). Retrieved May 08, 2017, from https://www.youtube.com/watch?v=p-iF14qhBsE

Emerging Leaders Papers (Rep.). (n.d.).

Gloria Steinem and Emma Watson pledge support to end child marriage. (2016, June 6). Retrieved May 08, 2017, from https://camfed.org/latest-news/gloria-steinem-emmawatson-end-child-marriage/

Goodhart, M. E. (2012). Human rights: politics and practice. Oxford: Oxford University Press. Guggenheim, D. (Director). (2016). Malala = (He named me Malala) [Video file]. Milano: Mondadori. Retrieved from https://www.malala.org/host-a-screening 
Hudson, V. M. (2012). Sex and World Peace. Columbia University Press.

International Covenant on Economic, Social and Cultural Rights. (n.d.). Retrieved February 20, 2017, from http://www.ohchr.org/EN/ProfessionalInterest/Pages/CESCR.aspx

Kestler-D'Amours, J. (2017, April 13). Malala Yousafzai made an honorary Canadian citizen. Retrieved May 03, 2017, from http://www.aljazeera.com/news/2017/04/malalayousafzai-honorary-canadian-citizen-170412173952908.html

Komives, S. R., \& Wagner, W. (2009). Leadership for a better world: understanding the social change model of leadership development. San Francisco, CA: Jossey-Bass, A Wiley Brand.

Kristof, N. D., \& WuDunn, S. (n.d.). Support Smart Girls. Retrieved February 20, 2017, from http://www.halftheskymovement.org/

Malala Fund (n.d.). Learning for 12 years. Leading without fear. Retrieved May 01, 2017, from http://www.malala.org/

Reilich, G. (2016, March 14). If The World Were 100 People | GOOD Data. Retrieved April 24, 2017, from https://www.youtube.com/watch?v=QFrqTFRy-LU

Shea, C. (2017, May 08). Emma Watson Wins MTV's Gender-Neutral Acting Prize. Retrieved May 09, 2017, from https://www.nytimes.com/2017/05/08/movies/emma-watson-mtvgender-neutral-acting-prize.html

Universal Declaration of Human Rights. (n.d.). Retrieved February 20, 2017, from http://www.un.org/en/universal-declaration-human-rights/index.html Yousafzai, M., \& Lamb, C. (2013). I am Malala: the girl who stood up for education and was shot by the Taliban. New York, NY: Little, Brown. 
Yousafzai, M. (2014, October 10). Standing up for girls. Retrieved May 01, 2017, from http://www.washingtonpost.com/opinions/malala-yousafzai-helping-girls-worldwiderequires-a-united-stand/2014/07/13/14ccf54c-0920-11e4-8a6a-19355c7e870a_story.html 


\section{Appendix}

\section{Pre-Screening Survey Questions}

You are invited to join a research study to look at the Social Change Model of leadership and women's rights to education. In this research study, we are investigating opinions and beliefs about the effectiveness of film screenings to create change.

If you decide to participate you will be asked to complete an online survey, which will take approximately 5 minutes.

Participation in this study is voluntary. You have the right not to participate at all or to leave the study at any time. Deciding not to participate or choosing to leave the study will not result in any penalty. Your responses will be kept strictly confidential, and all participants will be assigned a number to ensure complete anonymity.

Please contact Abbey Solnet if you have questions about the study, any problems, unexpected physical or psychological discomforts, any injuries, or think that something unusual or unexpected is happening. (303-704-7760; solnetar@sandiego.edu)

Signature:

Date: 


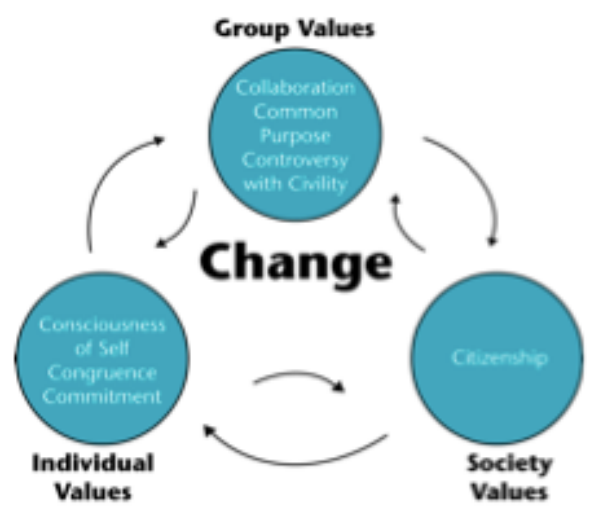

How familiar are you with the Social Change Model?

Unfamiliar Somewhat unfamiliar Neither/nor Somewhat familiar Familiar

Have you heard of Malala Yousafzai?

Yes Unsure No

Have you heard of the film "He Named Me Malala"?

Yes Unsure No

Please select your likelihood to do the following:

\begin{tabular}{l|ccccc} 
& Unlikely & $\begin{array}{c}\text { Somewhat } \\
\text { Unlikely }\end{array}$ & $\begin{array}{c}\text { Neither Likely } \\
\text { Nor Unlikely }\end{array}$ & $\begin{array}{c}\text { Somewhat } \\
\text { Likely }\end{array}$ & Likely \\
\hline $\begin{array}{l}\text { Donate money to the Malala } \\
\text { Fund }\end{array}$ & 0 & 0 & 0 & 0 \\
$\begin{array}{l}\text { Sign up for email updates } \\
\text { from the Malala Fund }\end{array}$ & 0 & 0 & 0 & 0 \\
$\begin{array}{l}\text { Watch the film "He Named } \\
\text { Me Malala" }\end{array}$ & 0 & 0 & 0 & 0
\end{tabular}

What would increase your likelihood to get involved with education advocacy? (short answer)

How many school-age girls are not in school (k-12)? (short answer)

Why do some girls not continue their education? (select all that apply) 
Options: poverty, forced to marry, violence, traditions that do not value girls learning, costs of school supplies, take care of younger siblings

What are benefits to gender equality in education? (select all that apply)

Options: ending child marriage, economic benefits, increased wages, lower deaths of children, and giving girls and women the confidence and knowledge to take part in the sustainable development of their communities and countries

To which gender identity do you most identify?

Female, Male, Other, Prefer not to answer

\section{Post-Screening Survey Questions}

You are invited to join a research study to look at the Social Change Model of leadership and women's rights to education. In this research study, we are investigating opinions and beliefs about the effectiveness of film screenings to create change.

If you decide to participate you will be asked to complete an online survey, which will take approximately 5 minutes.

Participation in this study is voluntary. You have the right not to participate at all or to leave the study at any time. Deciding not to participate or choosing to leave the study will not result in any penalty. Your responses will be kept strictly confidential, and all participants will be assigned a number to ensure complete anonymity.

Please contact Abbey Solnet if you have questions about the study, any problems, unexpected physical or psychological discomforts, any injuries, or think that something unusual or unexpected is happening. (303-704-7760; solnetar@sandiego.edu) 
Signature:

Date:

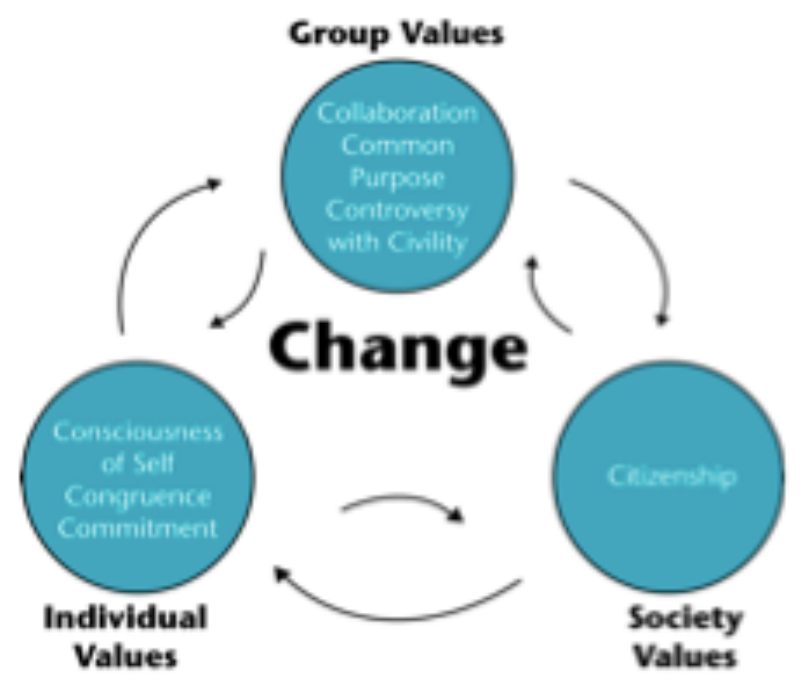

How familiar are you with the Social Change Model?

Unfamiliar Somewhat unfamiliar Neither/nor Somewhat familiar Familiar

Please select your likelihood to do the following:

\begin{tabular}{l|ccccc} 
& Unlikely & $\begin{array}{c}\text { Somewhat } \\
\text { Unlikely }\end{array}$ & $\begin{array}{c}\text { Neither Likely } \\
\text { Nor Unlikely }\end{array}$ & $\begin{array}{c}\text { Somewhat } \\
\text { Likely }\end{array}$ & Likely \\
\hline $\begin{array}{l}\text { Donate money to the Malala } \\
\text { Fund }\end{array}$ & 0 & 0 & 0 & 0 & 0 \\
$\begin{array}{l}\text { Sign up for email updates } \\
\text { from the Malala Fund }\end{array}$ & 0 & 0 & 0 & 0 & 0 \\
$\begin{array}{l}\text { Recommend the film "He } \\
\text { Named Me Malala" to a } \\
\text { friend }\end{array}$ & 0 & 0 & 0 & 0
\end{tabular}

What would increase your likelihood to get involved with education advocacy? (short answer)

How many school-age girls are not in school (k-12)? (short answer) 
Why do some girls not continue their education? (select all that apply)

Options: poverty, forced to marry, violence, traditions that do not value girls learning, costs of school supplies, take care of younger siblings

What are benefits to gender equality in education? (select all that apply)

Options: ending child marriage, economic benefits, increased wages, lower deaths of children, and giving girls and women the confidence and knowledge to take part in the sustainable development of their communities and countries

To which gender identity do you most identify?

Female, Male, Other, Prefer not to answer 